\title{
Managing soil acidity: old solutions can cause new problems
}

R.A. CARRAN

AgResearch Grasslands, Private Bag 11008, Palmerston North, New Zealand

\begin{abstract}
Acid and moderately acid soils (pH 5-6) are widespread in the farmed areas of New Zealand. Application of limestone to raise soil $\mathrm{pH}$ has been a common practice and re-acidification of soils requires that this be done regularly. The impact of liming and re-acidification cycles on soil chemistry is discussed and examples presented using a Southland soil: Waimumu silt loam. Wide ratios of $\mathrm{Ca}: \mathrm{Mg}$ develop in the soil and further lime application is shown to damage growth of white clover but not Grasslands Tama ryegrass. Differences in surface chemistry of roots of legumes and grasses are discussed and the implications of the interactions between changes in soil chemistry and plant roots considered.
\end{abstract}

Keywords acidification, calcium, magnesium, cation ratio, root $\mathrm{CEC}$

\section{Introduction}

The management of soil acidity is an issue that is continually confronting farmers in many parts of New Zealand and especially those of Southland and Southern Otago. Carbonate ions, which are in equilibrium with limestone in soils and raise $\mathrm{pH}$, are leached from the soil or react with the acids produced by many biological processes (Bolan et al. 1991). Limed soils therefore inevitably drift back toward the original, unlimed, $\mathrm{pH}$ of the soils. The land user is then required to make decisions about reliming. These decisions have often been made on the basis that what worked once will work again so lime is reapplied on a basis determined by $\mathrm{pH}$ guidelines and available finance. Significant numbers of lime rate trials have shown negative yield responses to lime (that is a reduction in yield with increasing $\mathrm{pH}$ ) especially in reliming situations (Pringle et al. 1985; Floate \& Cossens 1985). The soils in the southern South Island seem to present particularrisks in this regard (Cornforth \& Sinclair 1984). Negative yield responses to liming occur quite frequently in acid, strongly weathered soils of tropics, a condition caused by fixation of phosphorus $(\mathrm{P})$, magnesium $(\mathrm{Mg})$ and zinc $(\mathrm{Zn})$ by alurninium hydroxy compounds formed when the soil is limed
(Grove \& Sumner 1985). The negative yield responses to liming recorded with some South Island high country soils (Lowther \& Adams 1970) may be due to similar mechanisms. In less weathered and less acid soils alternative explanations are necessary. Carran (1991) has shown that where wide calcium $(\mathrm{Ca})$ to $\mathrm{Mg}$ ratios are produced by liming clover yield can be reduced.

This paper takes those findings and discusses them in relation to: the chemical changes that occur in soils that are limed and acidified and relimed. the differential responses of plants, and the impact of their root chemistry on response to liming. The discussion uses Waimumu silt loam as an example and considers the practical steps to be taken in managing soil acidity in ways that recognise the changes wrought by past management.

\section{Methods}

1) Effect of liming and re-acidification on soil properties

Soils were collected from roadside areas in the Waimumu-Charlton area that were sufficiently large to have avoided modification by road building and inputs of lime from adjacent farmland, and from areas intensively farmed with a history of limestone application. Samples were analysed for $\mathrm{pH}\left(1: 2.5\right.$ in $\left.\mathrm{H}_{2} \mathrm{O}\right)$; exchangeable calcium $(\mathrm{Ca})$, magnesium $(\mathrm{Mg})$, potassium $(\mathrm{K})$ and aluminium $(\mathrm{Al})$ (molar, neutral ammonium acetate leaching followed by flame photometry or atomic absorption spectroscopy). Effective cation exchange capacity (ECEC) was calculated by summing cations and cation exchange capacity at $\mathrm{pH} 7$ by determining ammonium adsorbed from the leaching process.

2) Effect of soil $\mathrm{pH}$ and $\mathrm{Ca}: \mathrm{Mg}$ ratios on plant growth Full details are available in Car-ran (1991). Equivalent mixtures of $\mathrm{CaCO}_{3}$ and $\mathrm{MgCO}_{3}$ were thoroughly mixed through Waimumu silt loam to provide $4 \mathrm{pH}$ values: 5.2 (unlimed), 5.4,5.8 and 6.1 with four $\mathrm{Ca}: \mathrm{Mg}$ ratios at each of the limed $\mathrm{pH}$ values, 100:0,90:10,75:25 and 50:50. Basal nutrients (except $\mathrm{N}$ for white clover) were added and white clover (cv. Grasslands Huia) or Lolium multiflorum (4n Westerwolds cv. Grasslands Tama) planted. Harvest was after 42 days and dry matter yield determined. 
Table 1 Some properties of Waimumu silt loam before liming and after liming and natural re-acidification.

\begin{tabular}{|c|c|c|c|c|c|c|c|c|}
\hline & $\begin{array}{c}\mathrm{pH} \\
\left(\mathrm{H}_{2} \mathrm{O}\right)\end{array}$ & $\mathrm{c} \mathrm{a}$ & $\mathbf{M g}$ & $\begin{array}{c}\mathrm{N} a \\
\mathrm{me} \%\end{array}$ & k & A & ECEC & $\begin{array}{l}\text { CEC } \\
\mathrm{pH} 7\end{array}$ \\
\hline unilmed & $5.2-5.4$ & $3-5$ & I-I.2 & 0.1 & 0.3 & 0.1 & 5.5 & 18 \\
\hline limed and actidified & $5.2-5.4$ & $8-10$ & $0.6-I$ & 0.1 & 0.3 & 0 & 11 & 16 \\
\hline
\end{tabular}

3) Root CEC and Ca adsorption

Plants were grown in 9-litre containers of aerated complete nutrient solution to provide a suitable mass of roots for analysis. Root CEC and Ca adsorption were determined using the methods of Wacquant (1977).

\section{Results and Discussion}

1) Effect of liming and re-acidification in soil properties

Areas of soil unaffected by lime or Ca based fertiliser are hard to find in agricultural areas. The data in Table 1 are derived from road reserve areas in the Waimumu area and should approximate the initial soil $\mathrm{pH}$ and cation status for Waimumu soils and a typical set of values for a soil that has been limed and later acidified. An important feature is the alteration in $\mathrm{Ca}$ content and $\mathbf{C a}: \mathbf{M g}$ ratio. It is from these differences that the effect of lime applicationneeds to be considered. In the first case, liming a previously unlimed soil at a rate of $5 \mathrm{t} / \mathrm{ha}$ of limestone results in $\mathbf{p H}$ increasing to $>6$ and Ca increasing by about 10 me.\% to 13-14 me.\%. In the second case, a similar amount of lime would affect $\mathbf{p H}$ similarly but exchangeable $\mathrm{Ca}$ would increase to around 20 me.\%.

In practice these changes may be less clear cut because agricultural limestone has a range of particle sixes and dissolves progressively, and not instantly, and surface-applied material takes time to move into the soil. Extreme changes occur on the surface therefore. but these become less pronounced as the dissolved material moves down into the soil.

During the following period when the products of dissolution $\left(\mathrm{Ca}^{++}\right.$and $\mathrm{HCO}$ ions) are being lost from the soil, further changes occur. The dominant cation lost is Ca during acidification but $\mathrm{Mg}$ is lost also, and although the absolute amount is small in relation to total cation losses, this has an additional impact on the ratio of $\mathrm{Ca}$ to Mg.

2) Effects of soil $\mathbf{p H}$ and $\mathrm{Ca}: \mathrm{Mg}$ ratio on plant growth Under the condition of wide $\mathbf{C a}: \mathbf{M g}$, reliiing appears to be harmful (Table 2) and depressions of growth of white clover after liming may occur. Substituting $\mathrm{MgCO}_{3}$ for $\mathrm{CaCO}_{3}$ at equivalent rates, reduces and
T able2 The effect of $\mathrm{pH}$ and the $\mathrm{Ca}: \mathrm{Mg}$ ratio of liming material on yield of white clover grown in Waimumu silt loam (g/pot) which had been limed and re-acidified subsequently.

\begin{tabular}{lcccc}
\hline Ca:Mg & $\begin{array}{c}5.2 \\
\text { unllmed }\end{array}$ & 5.4 & 5.6 & 6.1 \\
\hline $100: 0$ & 2.35 & 2.33 & 1.09 & 1.43 \\
$90: 10$ & & 2.42 & 2.03 & 1.02 \\
$75: 25$ & & 2.54 & 1.92 & 1.57 \\
$50: 50$ & & 2.06 & 2.25 & 2.17 \\
LSD $_{\text {(a.05) }}$ & 0.30 (arty comparison) & \\
\hline
\end{tabular}

ultimately eliminates the depression of clover growth (Table 2). Carran (1991) has shown that although this is an apparent response to $\mathrm{Mg}$. a deficiency may not be indicated by plant analysis $(0.25 \% \mathrm{Mg}$ in controls) and that exchangeable $\mathrm{Mg}$ may be in the medium range $(0.8$ me.\% or greater). Plant $\mathrm{Ca}$, however, tended to be high (1.8\% or more) and the ratio of $\mathrm{Ca}$ to $\mathrm{Mg}$ in soil solution large (c. 9) wherever growth was depressed.

While the impact of these conditions seems clear when white clover is grown it is not apparent when Tama ryegrass (Lolium multiflorum, tetraploid Westerwolds) is used as the test crop (Table 3). Neither $\mathbf{p H}$ nor $\mathrm{Ca}: \mathrm{Mg}$ had any effect on yield of Tama, acultivarlmownforlow $\mathrm{Mg}$ content.

Table 3 The effect of $\mathbf{p H}$ and the $\mathbf{C a}: \mathbf{M}_{\mathbf{8}}$ ratio of liming material $\mathrm{cm}$ yield of Tama ryegrass grown in Waimumu silt loam (g/pot).

\begin{tabular}{lcccc}
\hline Ca:Mg & $\begin{array}{c}\text { 5.2 } \\
\text { unlimed }\end{array}$ & 5.4 & 5.8 & 6.1 \\
\hline $100: 0$ & 2.54 & 2.51 & 2.46 & 2.67 \\
$90: 10$ & & 2.59 & 2.46 & 2.54 \\
$75: 25$ & 2.45 & 2.56 & 2.42 \\
$50: 50$ & & 2.53 & 2.59 & 2.51 \\
& & no significant differences $(p=0.05)$ \\
\hline
\end{tabular}


Table 4 Root cation exchange capacity (CEC) and $\mathrm{Ca}$ adsorbed as $\%$ of total cations adeorbed from . solution $0.05 \mathrm{~N}$ in $\mathrm{C}, \mathrm{Mg}_{\mathrm{g}} \mathrm{K}$ and $\mathrm{Na}$.

\begin{tabular}{|c|c|c|c|}
\hline & Cultivar & CEC $(\mathrm{me} \%)$ & $\begin{array}{c}\mathrm{Ca} /(\mathrm{Ca}+\mathrm{Mg}+\mathrm{K}+\mathrm{Na}) \\
(\%)\end{array}$ \\
\hline \multicolumn{4}{|l|}{ Legumes } \\
\hline Medicago sativa & Oranga & 32 & 40 \\
\hline Tritolium repens & Hula & 20 & 35 \\
\hline \multirow[t]{2}{*}{ Tritolium pratense } & Pawera & 20 & 37 \\
\hline & Turoa & 19 & 52 \\
\hline Trifolium hybridum & Svea & 22 & 51 \\
\hline Lotus pedunculatus & Maku & 20 & 50 \\
\hline \multicolumn{4}{|l|}{ Crasses } \\
\hline Agrostis tenuis & Muster & 12 & 12 \\
\hline Agrostis castellana & & 7 & 19 \\
\hline Phleum pratense & Kahu & 12 & 21 \\
\hline Lolium multiforum ( $4 n$ Westerwolds) & Tama & 48 & 15 \\
\hline Lolium pefenne & Ruanul & 11 & 30 \\
\hline Bromus catharticus & Matua & 22 & 30 \\
\hline
\end{tabular}

3) Root CEC and Ca adsorption

Grasses and clovers have very different contents of $\mathrm{Ca}, \mathrm{Mg}$. Na. $\mathrm{K}$ when grown together, a difference that is related to the root cation exchange capacity (Haynes 1980; Wacquant 1977). Roots of plants like white clover and luceme (Medicago sativa) select strongly for $\mathrm{Ca}$ and $\mathrm{Mg}$ whileroots of grasses select more strongly for $\mathrm{K}$ and $\mathrm{Na}$.

This contrast is demonstrated in Table 4. Roots of the legumes selected very strongly for the divalent cations and those of the common pasture grasses selected much more strongly for the monovalent cations.

The changes in soil chemistry induced by liming, acidification and reliig obviously can interact strongly with plant species. Clovers are in a doubly difficult situation with both the soil solution chemistry and the root surface chemistry combining to load the rhizosphere with $\mathrm{Ca}$ and high plant $\mathrm{Ca}$ is an inevitable consequence. Grasses, on the other hand have a root chemistry that excludes $\mathrm{Ca}$ and therefore they never accumulate large amounts within the plant. The mixed pastures used throughout New Zealand therefore present a complex situation for analysing and predicting lime responses with components that differ in responses. The sensitivity of the nitrogen-fixing legume component to damage at high $\mathrm{Ca}: \mathrm{Mg}$ ratios is of particular concern.

\section{Conclusions}

The changes produced by liming, acidification and reliming cycles are pronounced. While $\mathbf{p H}$ is clearly a dynamic property which can increase or decrease over relatively short periods, the cation exchange properties show significant components of non-reversible change. Any programme for managing soil acidity needs to proceed from the basis that each time the liming-acidi- fication cycle rotates, a different response may be needed in terms of quantity and composition of liming material. Simply repeating the solutions that were initially successful may speed the development of problems.

Heavy, infrequent applications of limestone may need to be replaced with lighter more frequent applications, use of $\mathrm{Mg}$ containing materials like dolomite or magnesium oxide or non-liming policies. Clearly these alternatives have costs associated with them, and in the case of Mg inputs these could be high.

The different ways in which the grass and legume components of pastures react to varying soil composition and Calevels, in particular. adds furtheruncertainty to prediction of responses. Field experimentation with control of both $\mathrm{pH}$ and $\mathrm{Ca}: \mathrm{Mg}$ ratio must now be a priority if rational plans for managing soil acidity are to lx developed.

\section{ACKNOWLEDGEMENTS}

James Evans and David Tumer. DSIR Grasslands at Palmerston North and Gore for assistance in soil sampling, growing plants and analysing roots.

\section{REFERENCES}

Bolan, N.S.; Hedley. M.J.; White, R.E. 1991. Processes of soilacidificationduringnitrogencycling with emphasis on legume based pastures. Plant and soil 134: 53-63.

Carran, R.A. 1991. Ca induced Mg deficiency in clovers: A cause of negative yield response to liming. Plant and soil 134: 107-114.

Cornforth. IS.; Sinclair. A.G. (Eds.) 1984. Fertiliser recommendations for pastures and crops in New Zealand.NZ Ministry of Agriculture and Fisheries, Wellington, New Zealand. 66pp. 
Floate, M:G.S.; Cossens, G.C. 1985. Predicting limeresponse on pastures. In Proceedings of a workshop lime in New Zealand agriculture. Eds. B.L.T. Jackson and D.C.Edmeades.pp_7-9.NZ Ministry of Agriculture and Fisheries, Hamilton, New Zealand.

Haynes, R.J. 1980. Ion exchange properties of roots and ionic interactions within the root apoplasm: their role in ion accumulation in plants. The botanical review 46: 75-99.

Lowther, W.L.; Adams, A.F.R. 1970. The interaction of lime and phosphorus on nodulation and growth of white clover. NewZealandjournal of agricultural research 13: 252-262.

Pringle, R.M.; Edmeades, D.C.; Shannon, P.W.; Mansell, G.P. 1985. Predicting limeresponse onpastures. In Proceedings of a workshop lime in New Zealand agriculture. Eds. B.L.T. Jackson and D.C. Edmeades. pp 20-22. NZ Ministry of Agriculture and Fisheries. Hamilton, New Zealand.

Wacquant, J.P. 1977. Physic+chemical selectivity for cations and CEC of grass roots. Plant and soil 47: 257-261. 